\title{
Abbreviations
}

AIDS Acquired immune deficiency syndrome

DNR Donets'k People's Republic (Rus: Donetskaya Narodnaya Respublika)

EU European Union

HIV Human immunodeficiency virus

LNR Luhans'k People's Republic (Rus: Luganskaya Narodnaya Respublika)

MAT Medication-assisted treatment

$\mathrm{MoH} \quad$ Ministry of Health

PEPFAR President's Emergency Fund for AIDS Relief

SSR Soviet Socialist Republic

WHO World Health Organization

USAID United States Agency for International Development 


\section{Map of Ukraine}

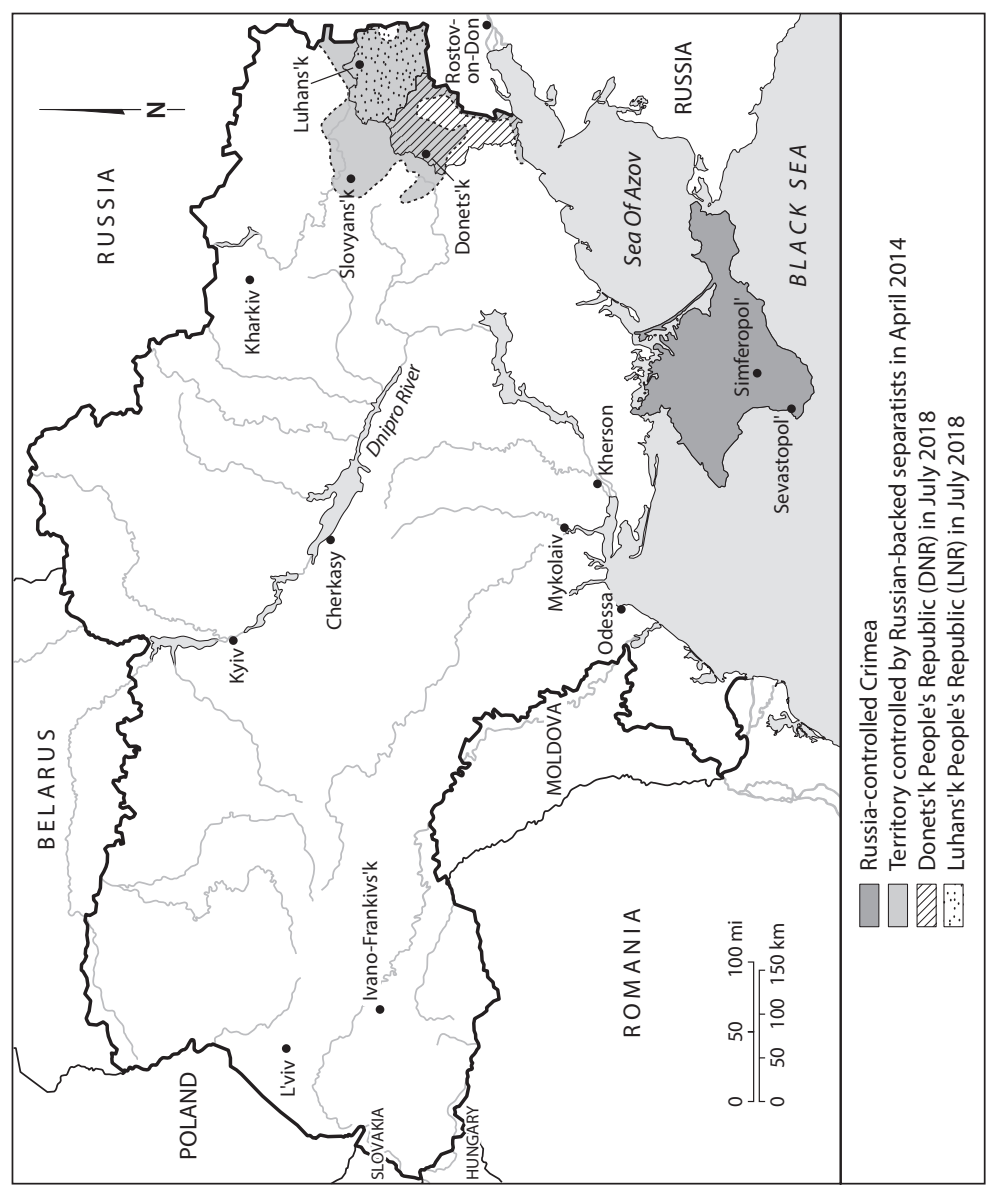



Narkomania 
